\title{
CAREER INFORMATION SERVICES TO IMPROVE CAREER DECISION MAKING
}

\author{
Nurfaizal ${ }^{1}$, Ainur Rosidah ${ }^{2}$ \\ Universitas Muhammadiyah Pringsewu Lampung \\ Email : nurfaizal@umpri.ac.id 1, ainurrosidah@umpri.ac.id ${ }^{2}$
}

\begin{abstract}
Abstrak
This research is derived from the problems faced in career decision making and providing conventional counseling and guidance services. The approach used is quantitative with a purposive sampling technique and research subjects are students of guidance and counseling study programs at STKIP Muhammadiyah Pringsewu. In collecting data, the researcher used documentation, interviews and questionnaires. The data were analyzed using paired sample $t$-tests. The results of the analysis showed that $\mathrm{T}$ count was $14,667>\mathrm{T}$ table 1,688 , so the hypothesis was accepted. The services provided indicate changes in students; 1) students' ability in career decision-making is in high categories, 2) Students are able to read opportunities and make career decisions, 3) the use of electronic media is very supportive in providing services.
\end{abstract}

Kata Kunci : information services, electronic media, career decision making

Website: http://ejournal.umpri.ac.id/index.php/fokus

\section{PENDAHULUAN}

Perkembangan teknologi informasi dan komunikasi yang sangat pesat mendorong berbagai lembaga pendidikan dalam memanfaatkan sistem pembelajaran elektronik ( $e^{-}$ learning) untuk meningkatkan efektivitas dan fleksibilitas pembelajaran. Melalui $e^{-}$ learning materi pembelajaran dapat diakses kapan saja dan dari mana saja, disamping itu materi yang dapat diperkaya dengan berbagai sumber belajar dengan cepat dapat diperbaharui oleh pengajar.

Proses pembelajaran dengan menggunakan sistem E-learning dapat dimanfaatkan dalam layanan bimbingan konseling baik pada sekolah maupun pada perguruan tinggi, terutama dalam pemberian layanan informasi. Pemanfaatan sistem $\mathrm{e}^{-}$learning tersebut dapat digabung dengan sistem pembelajaran konvesional yang dikenal dengan sistem blended learning atau hybrid learning. Menurut Surya (Nuryanti, 2004) perkembangan penggunaan media pembelajaran dari media yang bersifat konvensional ke media yang berteknologi, terutama teknologi komunikasi dan informasi mengakibatkan terjadinya lima penggeseran dalam proses pembelajaran, yakni: (1) dari pelatihan ke keterampilan , (2) dari ruang kelas ke mana dan kapan saja, (3) dari kertas ke "on line", (4) dari fasilitas ke fasilitas jaringan kerja, (5) dari waktu siklus ke waktu nyata.

Saat ini proses konseling juga tidak harus dilaksanakan secara langsung (face to face). Hadirnya layanan cybercounseling atau bimbingan dan konseling berbasis 
internet menjadi salah satu bukti bahwa konseling seharusnya tidak terbatas pada ruang dan waktu. Media elektronik yang berisikan informasi karir ini juga dapat dijadikan sebagai layanan konsultasi bagi Mahasiswa yang bingung dan masih ragu serta belum mampu untuk menentukan atau memutuskan arah pilihan karirnya ke depan. Sehingga Mahasiswa tidak kekurangan informasi dan lebih mampu untuk mengambil keputusan mengenai karirnya kedepan.

Perkembangan teknologi memungkinkan peserta didik mengakses informasi tanpa batas dari berbagai belahan dunia. Semakin berkembangnya ilmu pengetahuan teknologi, memungkinkan peserta didik untuk menjelajah berbagai informasi serta berinteraksi secara langsung dengan berbagai macam informasi yang ada di dunia maya (internet). Informasi yang diperoleh, dapat dijadikan sebagai sarana memperkaya wawasan bagi peserta didik untuk menjalani kehidupan sehari-hari.

Febry Yani Falentini, Tufik dan Mudjiran (2013). Salah satu tugas perkembangan yang harus dilalui oleh remaja adalah mencapai kematangan dan pengambilan keputusan karir di masa depan. Penelitian yang telah dilaksanakan oleh Febry dkk ini menjelaskan bagaimana usaha siswa dalam menentukan arah pilihan karir serta hambatan yang mereka temui. Untuk itu sebagai guru pembimbing maupun konselor agar dapat meningkatkan pelayanan dalam memberikan bantuan kepada siswa baik itu berupa informasi yang diperlukan oleh peserta didik maupun tes yang dapat mendukung demi kelancaran peserta didik untuk menentukan keputusan karir mereka. Kounenou (2014) dalam penelitiannya mengemukakan bahwa keraguan karir adalah salah satu masalah utama dalam pengambilan keputusan karier.

Dengan layanan yang mengikuti perkembangan zaman selain memanfaatkan teknologi untuk melakukan layanan informasi tetapi juga tetap memperhatikan azas dan kode etik dalam bimbingan dan konseling. Sehingga masalah yang dihadapi Mahasiswa untuk mengambil keputusan karir dapat dihindari ketika Mahasiswa memiliki sejumlah informasi yang memadai seputar karir.

Gibson dan Mitchell (2010:455) bahwa sesorang butuh untuk mempelajari proses pengambilan keputusan, ini dimaksudkan agar Mahasiswa secara sadar mengetahui tindakan yang diambil untuk masa depan mereka dari alternatif, konsekuensi yang ada, serta dapat merencanakan, melaksanakan, dan mengevaluasi keputusan yang telah dibuat. Maksud pengertian diatas Mahasiswa mempelajari proes pengambilan keputusan karir dapat dari pengalaman pribadi maupun orang lain lalu dievaluasi.

Ditambahkan oleh Brown (dalam Gibson dan Mitchell,2010:469) bahwa individu bertindak dan membuat keputusan yang dipengaruhi oleh nilai mereka sendiri. Dari pegertian diatas dapat disimpulkan bahwa nilai yang dimiliki individu akan mempengaruhi saat akan pengambilan keputusan, nilai yang di maksudkan disini bukan nilai akademis melainkan nilai personal yang dimiliki individu itu sendiri.

Donald E. Super (Hadiarni, 2009: 127) menyatakan bahwa karir yang akan dilalui oleh seseorang dipengaruhi oleh beberapa faktor, diantaranya :

a) Faktor yang terdapat pada diri individu itu sendiri berkaitan dengan bakat, minat, kemauan, sikap, kemampuan intelektual dan berbagai potensi diri lainnya

b) Faktor yang berada di luar diri individu diantaranya: taraf kehidupan social ekonomi keluarga, tuntutan lingkungan setempat, budaya yang berkembang, kesempatan atau peluang kerja yang tersedia.

Hal yang mendasar pada diri seseorang pada pemilihan pekerjaan atau keputusan karir adalah vocational self-concept yang merupakan sebagian dari keseluruhan gambaran tentang diri seseorang dan pekerjaan, hal ini akan mendorong seseorang untuk memasuki suatu pekerjaan atau karir tertentu. Perolehan informasi karir sangat berperan bagi kematangan karir seseorang, khususnya menjadi sebuah konsep yang 
paling penting dimasa remaja. Teori super memiliki konstruksi yang valid sehingga digunakan sebagai instrument yang membantu pekerajaan konselor.

Aspek-aspek pengambilan keputusan karir dikemukakan oleh Krumboltz dan Baker (dalam Sari, 2015:18), yang kemudian dijadikan kerangka pikir oleh penulis, hal yang penting dalam pengambilan keputusan karir adalah kemampuan untuk:

a) Mengakui pentingnya sebuah keputusan

b) Memeriksa dan menilai secara cermat dan tepat generalisasi observasi diri dan generalisasi pandangan atas dunia

c) Menyusun alternatif-alternatif yang luas dan beragam

d) Mengumpulkan informasi yang diperlukan tentang pekerjaan yang diminati

e) Menentukan keputusan yang harus diambil sesuai dengan pekerjaanyang diminati

f)Melaksanakan urutan langkah- langkah pengambilan keputusan tersebut.

Layanan informasi merupakan salah satu jenis layanan dari empat bidang bimbingan dalam BK yang secara menyeluruh meliputi bimbingan pribadi, sosial, belajar dan karir dari empat bidang bimbingan tersebut dapat diselenggarakan melalui tujuh jenis layanan yaitu; 1) layanan orientasi, 2) informasi, 3) penempatan/penyaluran, 4) pembelajaran, 5) konseling perorangan, 6) bimbingan kelompok dan 7) konseling kelompok.

Menurut Winkel dan Hastuti (1991:316) mengemukakan bahwa diadakannya layanan informasi untuk membekali para Mahasiswa dengan pengetahuan tentang data dan fakta di bidang pendidikan, bidang pekerjaan dan bidang pribadi-sosial, supaya mereka belajar tentang lingkungan hidupnya serta mampu merencanakan kehidupannya. Jadi dapat disimpulkan layanan informasi merupakan titik yang vital atau penting sebagai faktor pendukung yang diberikan kepada peserta didik dalam pelaksanaan program BK itu sendiri juga merupakan suatu proses bantuan yang diberikan.

Teknologi informasi dan komunikasi tidak lepas dari internet yang merupakan jaringan komputer terbesar di dunia, dengan menggunakan jaringan internet seseorang dapat mengakses informasi apa, dimana dan kapan saja yang tidak menutup kemungkinan untuk melakukan proses pembelajaran (Munir, 2009). Maksud pengertian diatas adalah banyak hal yang dapat diakses dengan menggabungkan teknologi informasi dan komunikasi dengan internet karena untuk mengakses sebuah informasi seseorang tidak harus menunggu lama dan dapat dilakukan dimana dan kapan saja, tentu saja informai yang ingin didapat juga tidak terbatas.

Menurut Gibson dan Michell (2010:134) juga menyatakan bahwa penyebaran informasi yang lebih baik menawarkan kesempatan bagi profesi konseling untuk menginformasikan semua segmen masyarakat via layanan-layanan yang relevan dan cara mengaksesnya. Dari pemaparan diatas dapat diambil kesimpulan bahwa potensi penngunaan teknologi informasi dalam BK mempermudah penyebaran informasi terutama untuk teknologi informasi dan komunikasi yang berbasis dengan internet.

\section{METODE}

Metode penelitian ini menggunakan pendekatan kuantitatif artinya data yang dikumpulkan berbentuk angka-angka yang nantinya dianalisis dengan rumus- rumus statistik dan merupakan penelitian eksperimen dengan bentuk One group Pretest Postest Design, pada metode ini terdapat pretest, sebelum diberi perlakuan, dengan demikian hasil perlakuan dapat diketahui lebih akurat karena dapat membandingkan dengan keadaan sebelum diberi perlakuan (Sugiyono, 2011:75). 
Penelitian ini dilaksanakan di STKIP Muhammadiyah Pringsewu, dengan populasi penelitian seluruh mahasiswa Program studi bimbingan dan konseling dengan jumlah 162 mahasiswa dengan jumlah sampel penelitian sebanyak 37 mahasiswa dan teknik sampling menggunakan purposive sampling (pertimbangan dan tujuan tertentu peneliti) pertimbangan berdasarkan kepemilikan smartphone serta pengguna aktif media di elektronik. Teknik pengumpulan data melalui dokumentasi, wawancara dan angket, kemudian angket pengambilan keputusan karir sebagai data utama dianalisis menggunakan program SPSS for windows versi 20 dengan teknik paired sample t-test.

\section{HASIL DAN PEMBAHASAN}

Penelitian ini bertujuan untuk mengetahui seberapa efektif layanan informasi karir untuk meningkatkan pengambilan keputusan karir dengan media elektromik. Setelah dilakukan proses penelitian diketahui mahasiswa memiliki tingkat pengambilan keputusan karir yang rendah, hal tersebut ditunjukkan dari hasil pemberian angket pretest dari 37 mahasiswa diperoleh 1 (2\%) Mahasiswa dalam kategori tinggi, untuk kategori sedang ada 31 (84\%) Mahasiswa, dan

kategori rendah terdapat 5 (14\%) Mahasiswa.

Setelah pretest selanjutnya dilakukan intervensi dengan layanan bimbingan dan konseling melalui media elektronik dengan tema materi; 1) aku mengenal diriku dan duniaku; 2) merencanakan karir ku; 3) simulai pengambilan keputusan karir.

Setelah intervensi dilakukan selanjutnya memberikan angket posttest dan didapatkan hasil 37 (100\%) mahasiswa pada kategori tinggi. Berdasarkan hasil pretest dan posttest angket pengambilan keputusan karir diatas, mahasiswa sebelum diberikan layanan informasi karir dengan rata-rata skor 61.46, sedangkan mahasiswa yang sesudah diberikan layanan dengan rata-rata skor 80.95. Hal ini menunjukan adanya peningkatan setelah diberikan layanan informasi karir berbasis media elektronik dengan selisih skor sebesar 19.49. Data yang digunakan dalam pengujian hipotesis yaitu data hasil skor pretest dan postest layanan informasi karir berbais media elektronik dapat dilihat melalui analisa uji-t menggunakan program SPPS versi 20 diperoleh tabel sebagai berikut:

\section{Tabel $1:$ Hasil Uji t}

\begin{tabular}{|c|c|c|c|c|c|}
\hline & Mean & $\mathrm{N}$ & Std. Deviation & Mean $^{\text {Std. }}$ & $\overline{\text { Error }}$ \\
\hline Pretest & 61,45 & 37 & 8,483 & ,394 & \\
\hline Posttest & 80,94 & 37 & 4,345 & 714 & \\
\hline
\end{tabular}

Berdasarkan hasil $t$ hitung diatas maka didapatkan $t$ hitung 14,667 $>t$ tabel 1,688 ini menunjukan bahwa setelah diberikan perlakuan berupa layanan informasi, mahasiswa memiliki perbedaan yaitu nilai yang meningkat dibandingkan sebelum diberikan perlakuan.

Proses pengambilan keputusan karir diawali dengan pengambilan pemilihan karir pada masa kanak-kanak. Pada masa ini sejalan dengan perkembangan rasa keingintahuan untuk memperoleh informasi dari pengamatan dan peran model-model, perkembangan minat, kecakapan, daya tahan, dan nilai-nilai akan berlangsung pada masa remaja. Perolehan informasi karir sangat berperan bagi keputusan karir seseorang, khususnya menjadi sebuah konsep yang paling penting dimasa remaja.

Layanan informasi merupakan suatu layanan yang sangat diperlukan diberbagai bidang kehidupan, juga pada layanan informasi karir, dengan layanan informasi ini maksud dan tujuan yang ingin disampaikan dapat segera mencapai sasaran yang 
diinginkan. Seperti yang dijelaskan oleh Gordon (2008: 4) bahwa informasi adalah data yang diproses kedalam suatu bentuk yang mempunyai arti bagi penerima dan memiliki nilai nyata yang dibutuhkan untuk proses pengambilan keputusan saat ini maupun saat mendatang.

Dalam menjalani kehidupannya, juga perkembangan dirinya, individu memerlukan berbagai informasi, baik untuk keperluan kehidupannya sehari-hari sekarang maupun untuk perencanaan kehidupannya ke depan. Informasi ini dapat diperoleh dari berbagai sumber, dari media lisan melalui perorangan, media tertulis dan grafis, melalui sumber formal dan informal, sampai dengan media elektronik melalui sumber teknologi tinggi (Prayitno, 2012: 49).

Departemen Pendidikan Nasional (2008: 225) mendefinisikan layanan informasi karir yaitu pemberian informasi tentang berbagai hal yang di pandang bermanfaat bagi peserta didik melalui komunikasi langsung (melalui media cetak, maupun media elektronik seperti, buku, brosur, leaflet, majalah dan internet).

Layanan informasi karir menurut Nursalim dan Suradi 2002: 22 adalah kegiatan bimbingan yang bermaksud membantu siswa untuk mengenal lingkungannya, yang sekiranya dapat dimanfaatkan untuk masa kini maupun masa yang akan dating.

Wibowo (2004:17) mengatakan bahwa, layanan informasi merupakan layanan bimbingan dan konseling yang memungkinkan peserta didik (klien) menerima dan memahami berbagai informasi (seperti informasi pendidikan dan informasi jabatan) yang dapat digunakan untuk bahan pertimbangan dan pengambilan keputusan peserta didik (klien). Peserta didik yang telah menerima layanan informasi dapat memahami informasi yang lebih dalam atau luas.

Dari pendapat ahli di atas, maka peneliti menyimpulkan bahwa layanan informasi karir adalah layanan bimbingan dan konseling yang memungkinkan peserta didik (klien) menerima dan memahami berbagai informasi (seperti informasi pendidikan dan informasi jabatan) yang dapat digunakan untuk bahan pertimbangan dan pengambilan keputusan peserta didik (klien), baik untuk keperluan kehidupannya sehari-hari sekarang maupun untuk perencanaan kehidupannya ke depan. Informasi ini dapat diperoleh dari berbagai sumber, dari media lisan melalui perorangan, media tertulis dan grafis, melalui sumber formal dan informal, sampai dengan media elektronik melalui sumber teknologi tinggi (melalui media cetak maupun media elektronik, seperti buku, brosur, leaflet, majalah dan internet.

Penggunaan perangkat media elektronik dalam proses bimbingan dan konseling tentu tidak berbeda dengan penggunaan media dalam proses belajar, sebab manusia adalah aktor utama dalam penggunaan multimedia, oleh karena itu dalam penggunaan aplikasi atau program multimedia harus mempertimbangkan pula aspek lingkungan psikososial manusia itu sendiri.

Istilah multimedia dapat diartikan dalam berbagai perspektif. Perspektif pertama yaitu konsep multimedia offline yang mengartikan multimedia sebagai sebuah presentasi langsung saat sekelompok orang duduk dalam sebuah ruangan sambil memandang gambar-gambar yang disajikan dalam satu atau lebih layar lebar dan mendengar musik atau suara lain yang disampaikan oleh pembicara. Sedangkan dalam perspektif online multimedia interaktif berarti manusia yang sedang mengamati server atau berinteraksi langsung dengan internet dan menerima presentasi yang terdiri atas teks on-screen, grafik dan animasi onscreen dan speaker yang datang dari speaker komputer (Mayer, 2009: 3).

Dalam kedua perspektif tersebut ada kesamaaan dalam hal adanya presentasi baik yang ditunjukkan secara langsung melalui pengamatan layar lebar dalam sebuah ruangan maupun melalui interaksi secara online melalui media internet. Dalam 
penelitain ini peneliti lebih menitik beratkan pada media elektronik sebagai sumber untuk menyampaikan informasi karir dalam rangka pengambilan keputusan karir.

Seperti pendapat yang dikemukakan oleh Gibson dan Michell (2010:134) “...konselor harus membantu klien dengan berbagai cara salah satunya dengan menggunakan media elektronik. Teknologi dirancang untuk memperbaiki hidup dan bukan meyulitkan mereka" artinya konselor dituntut untuk lebih mengikuti teknologi yang berkembang saat ini sebelum mereka membantu klien melalui perangkat teknologi itu sendiri. Berdasarkan rujukan yang sesuai dengan data statistik yang telah didapat, layanan informasi karir dengan berbasis pada media elektronik efektif untuk meningkatkan pengambilan keputusan karir mahasiswa program studi bimbingan dan konseling.

\section{SIMPULAN}

Berdasarkan data keseluruhan proses penelitian yang dilakukan, dapat ditarik kesimpulan bahwa layanan informasi karir berbasis media elektronik efektif untuk meningkatkan pengambilan keputusan karir mahasiswa STKIP Muhammadiyah Pringsewu, dengan $t$ hitung 14,667 $>t$ tabel 1,688, sehingga hipotesis diterima.

Pemberian layanan menunjukan adanya perubahan; 1) kemampuan pengambilan keputusan karir mahasiswa pada kategori tinggi, 2) Mahasiswa sudah mampu membaca peluang dan mengambil keputusan karir, 3) penggunaan media elektronik sangat menunjang dalam pemberian layanan.

\section{DAFTAR PUSTAKA}

Depdiknas. (2008). Penataan Pendidikan Profesional Konselor dan Layanan Bimbingan dan Konseling dalam Jalur Pendidikan Formal. Jakarta: Departemen Pendidikan Nasional.

Febry Yani Falentini, Tufik dan Mudjiran. 2013. Usaha yang Dilakukan Siswa dalam Menentukan Arah Pilihan Karir dan Hambatan-Hambatan yang Ditemui. Jurnal Pendidikan. Padang: Universitas Negeri Padang.H.1-8

Gibson, R. L., Mitchell., M. H. (2010). Bimbingan Dan Konseling. (Seventh Ed). Indonesia: Pustaka Pelajar.

Gordon, D.B. (2008). Kerangka Dasar Sistem Informasi Manajemen. Bagian I: Pengantar. Alih Bahasa: Andreas S. Adiwardana. Jakarta. PT. Pustaka Binawan Pressindo.

Hadiarni, I. (2009). Konseling Karir. Batu Sangkar: STAIN Batu Sangkar Press

Kounenou, K. (2014). Career indecisiveness and personality in Greek High school students. International Journal of Psychology and Counselling. 6(1). January. H.1-9.

Mayer, R.E. (2009). Multimedia Learning: Prinsip-Prinsip dan Aplikasi. Yogyakarta: Pustaka Pelajar

Munir. (2012). Pembelajaran Jarak Jauh. Bandung: Alfabeta

Sari, Y. R. P. dan dkk. (2017). "Pengembangan Panduan Mengakses Informasi Pekerjaan Melalui Internet Pada siswa SMK”. Jurnal. Consilium 5 (2).101-107 
Sugiyono. (2011). Metode penelitian kuantitatif kulaitatif dan R\&D. Bandung: Alfabeta

Nursalim, M. dan Suradi, S.A. (2002). Layanan Bimbingan dan Konseling. Surabaya: Unipress

Nuryanti, L. B. (2004). "Model Pembelajaran E-Leraning Melalui Hompage Sehingga Diharapkan Dapat Meningkatkan Minat Dan Kreativitas siswa”. [online]. Tersedia: http://jurnal.upi.edu/file/Lena.pdf [07 november 2018]

Wibowo, M.E. (2004). Konseling Kelompok Perkembangan. Semarang: Unnes Press.

Winkel, W. S. (1997). Bimbingan dan konseling disekolah menengah. Jakarta: Grasindo 